\title{
Prolegomenon $^{1}$
}

\section{Nemesis and Athena}

I am writing this prolegomenon while I am living like a hermit. A pandemic is raging across the world. Under governmental order my movements are severely restricted. I should absolutely avoid to get close to anyone except my wife. Countries are shut down. Travels have ceased. Economies are damaged. The practice of citizenship is extinguished almost entirely. We have to fear for our lives. This is the news that streams in from all sides, incessantly.

Certainly, we need not despair. Our world will endure. Differently, however. Lessons will be drawn. Such as the one a friend in France has drawn and shared with me. He held high positions in the government of his country, is a well-read person and a keen observer of political and civilizational developments. "This catastrophe", he observed, "represents an excellent lesson in humility for arrogant humankind that believes itself able to master the material and existential problems of the world with the instruments of technology alone. Contrary to what the new thaumaturges wish us to believe, that artificial intelligence, the benefits of which they boast with much clamor, is hardly of any help to us against a malignant virus. This brutal reminder of our individual and collective fragility will perhaps induce our societies to correct their chaotic trajectories and find again the path of wisdom."

My friend's observation carries in fact two lessons. The first is: Humankind has been possessed by an unfounded arrogance. And the second is: The ways of humans ought to be corrected and be wise ones again. The ethical insights expressed by these lessons are old - and have been largely forgotten. In "ancient" times they were, to everyone's knowledge, personified by divinities. If we turn to the pantheon of Greek gods, for instance, we see there Nemesis, the goddess who punishes hubris, and Athena, the goddess of wisdom. Both of course were held to be forces in human life, and therefore feared, as in the case of Nemesis, or invoked, as in the case of Athena.

Through the figure of Nemesis people in "ancient" times would have known, before any advancement unto pride, the lesson: Do not commit hubris! The knowledge did not necessarily constitute a guarantee against flares of arrogance, of course. But the powerful presence of the goddess in the prevailing mental cul-

1 EDITORIAL NOTE: This Prolegomenon was written by the author in English for the present English edition of the book. 
ture signified a distinct ethical warning. Be aware of the punishment pride entails!

Injunctions, to be accepted, need to be embedded in an intelligible moral whole. There were many deities in the Greek pantheon, and among them goddesses and gods, of course, who embodied the precepts that engender, if followed, a good life. Of these precepts wisdom undoubtedly is decisive. It was personified by no less a figure than Athena, the favorite daughter of the king of the Olympian gods, Zeus. Through the figure of Athena people in "ancient” times knew a life determined by the virtues of civilization, peace, civic courage, justice. Again, the presence of Athena in the prevailing mental culture did not necessarily prevent moral carelessness, reckless behavior, injudicious decisions and actions. But the very high position the goddess held in the pantheon and the many tales of her deeds signified for everyone the great promising power that is inherent to wisdom. Win your life, in undertaking it wisely!

\section{The Modern Discourse}

Knowledge matters. Knowledge personified is persuasive, besides. The "ancients" had an advantage over contemporary humankind, the "moderns", in having represented by their pantheon the ethic that humans ought to respect. Ethical rules may slip into the back of one's mind, Nemesis, once visualized, does not. Is Athena present, in the shape of statues, sculptures, relievos, she renders wisdom real in one's perception, and there, in one's mind, the tales of her wise and just deeds are freshened. What is required in terms of individual and social ethics is thus made generally intelligible.

Yes, the "ancients" had here an advantage over the "moderns". But the advantage derives from a mental, and not a concrete difference. Pride is a common notion, as is wisdom. Is the distinction that we have drawn between "ancients" and "moderns" therefore artificial? Yes, if we think of the commonality of ethical notions such as pride and wisdom. No, however, if we consider the particular mentality that we associate with the term "modern". In formulating his lesson my French friend had in mind a humankind sturdily on the path of modernity. "Moderns" overtaken by arrogance. "Moderns" that had strayed from the paths of wisdom. "Moderns" for whom humility is a foreign word. May we, for a justness of our considerations, nevertheless ask: Is the appeal to our sense of disinterest not called for? Is, indeed, human existence not essentially fragile?

It is not. This is the response, if, for an echo to our question, a modern mentality is assumed. To a representative of this mentality the lessons we are talking 
about hardly make sense. He (or she) knows his (or her) discourse ${ }^{2}$. It is an ideologically closed discourse. Of much sophistication, we might say. Are you questioning the premises of the modern Weltanschauung? You doubt my belief in man's lordly status in the world and you say this is pride? You query my enthusiasm about the tremendous progress humans have made in conquering nature and employing it, together with all the fantastic devices they are fabricating, for the purpose of attaining an ever more pleasurable life, and you say this is an anthropocentric folly? Well, be calm. There is no reason to worry about our modern Weltanschauung. That it is criticized is part of it. There are many different interpretations of modernity. They are all supposed to hold up a mirror to modernity. I do not refute what you say. For with your criticism you practice, I am greatly pleased to be able to note, a profoundly modern attitude. Whatever there is, let us be clear, is a subject of debate. All is negotiated. Nothing, for us, is solid. All melts in the modern mind. Isn't that infinitely interesting? ${ }^{3}$

Our objections escape our modern friend. The discourse within which she moves is perfectly self-contained. It makes her deaf, we could also say, to anything that would require an acquaintance with another kind of discourse. If there were, to be ascertained in the past, such a kind or, rather, such other kinds of discourse, then they are perceived, if they are perceived, as antique material that is of interest only to cultural antiquarians. They might live on by gracious acts of remembrance. Or they are just ignored. How could I speak of Nemesis, of Athena? Somehow seriously, indeed? What manner of discoursing have you chosen? Our modern friend could ask, probably quite puzzled.

Well, our friend is guessing right. We vary from the discourse that she is observing. In a probably unsuspected way, however, we should explain at once. We certainly do not refrain from pursuing our considerations on our chosen topic -

2 To avoid the awkward "he (or she)" we shall assume for our representative the female gender and shall henceforth use the pronouns "she" and "her".

3 Friedrich von Schlegel, German philosopher, literary critic, and writer of the Romantic period (on his life and work see the entry in the Stanford Encyclopedia of Philosophy: https://plato. stanford.edu/entries/schlegel/), developed in his text Ueber das Studium der griechischen Poesie (1795-96) a penetrating interpretation of the modern mentality. The principle of all modern poetry (the poetry written at his time), he stated, was a "supremacy of the 'Interesting"'. Its purpose was to incite, to captivate, and this by all means. As there always appeared something to be more interesting than that which presently was interesting, the modern poet was engaged in a pursuit of an infinite reality, an endless perfection. Unable to reach his goal, he was increasingly seized by an unfulfilled nostalgia, by a yearning for the infinite, and, ultimately, by despair. For the German text see: Friedrich Schlegel, Sämtliche Werke, Vol. 5, Vienna: Jakob Mayer und Compagnie, 1823, pp. 7-218. See furthermore my "Note on Modernity" which includes a section on Schlegel's text, in: Political Theory, Vol.7, No.1, Feb. 1979, pp. 123-137. 
modernity - in line with the stated narrative of modernity. We have to know how the modern mind works and what it is that it produces, intellectually, culturally, socially. We redo the modern discourse. It will appear here unflawed. Naturally, a major part of our work will therefore be an inquiry into the birth, the sources, and the growth of the modern idea. They ought to be exposed. It is in this state, then, that the modern idea, viewed in all its purity, fully displays its curious character. While it is meant to be actualized, it is destined never to be actualized. The modern idea molds by itself into a fiction.

We cannot but vary from the modern discourse. The reality of the fiction it is concerned with, is one thing. To appraise this phenomenon, is another. Such a project requires a language of comparison. Discourses other than the modern one have to be used in order to ascertain the latter's particular character. We shall rely therefore on such discourses for comparative purposes. It will be possible to contrast the narrative of modernity with narrative elements that not only are quite different from it, but actually entirely outside it. Thus, a critical language can be built up that is immune to the modern discourse. Our modern interlocutor will be puzzled. Why can my modern mind not just absorb what I am told?

\section{The Crucial Notion: Limits}

Yours is a special perception, we might reply. It filters and it frames. Be not surprised. You see things in your way. You have your notions in your mind. You judge by your measures. Oh, our modern friend will probably retort, what is wrong with that? Do have I not the right to hold the views that I claim to be mine? Of course, we shall say, you can entertain your views. This is not the problem. The difficulty lies elsewhere. Would you really be prepared or, rather, be able, we should now be compelled to ask, to enter into a dialogue with us? To understand us, as we understand you? Might you become aware of your curious position: You think your modern discourse is, as to the life and destiny of humankind, the exclusive one, while this is certainly not the case? You think you represent the latest in epistemology and can therefore sublimely postulate that all knowledge is discursive and suppose that the revelation of reality called truth occurs through processes of universal communication? While, as a matter of fact, reality epistemically is diluted?

As we shall see toward the end of the book, with the last chapter, people who are modern minded can indeed, as to the curious mental position they are accustomed to, waver and assume assessments of the human actuality outside the modern view. The pressure of reality that comes from the power structure of 
human life proves to be too strong. If the pure maintenance of your existence is at stake, the modern fiction appears to be of no help. You delve into your genuine knowledge of human nature, the empiricism of it, and anthropological lessons reappear that render you wise midmost your modern temperament. The result, surprising but logical, is the judicious system of constitutional government.

"Limits" is the crucial notion of this system. It is a decidedly non-modern notion. Let us consult our modern friend, not that we are mistaken. What will she say about limits? About the suggestions the notion implies? Knowing her, we should hardly be astounded by what she adamantly states: Limits? You speak of limits? To us, the people of modernity? You do not seem to have grasped our view. Let me pronounce it plainly: We can do whatever we can think of; we bring about whatever we undertake to bring about; we carry out whatever we are excited about carrying out. Nothing is farther from us than a limit to the expansion of our power to attain what we want to attain, to take possession of what we want to possess, to enjoy what we feel like enjoying. Everything is at our disposal, nothing is immune to our power. And if anyone speaks of limit or limits, we refuse to listen or reject it. Limits do not belong in our civilization, the modern civilization. ${ }^{4}$

In response, we shall remind our friend of the unsteadiness of all the modern pursuit, strikingly reflected today by so many interpreters of the contemporary human world. Our first chapter documents their views - and their paramodern conclusions. Will she demur? Or show herself inclined to examine our material? Even consider perhaps our diachronic diagnosis put forward later in the book? Concerning the historical reality of modernity, as it appears to have split apart, into a history "I", the projected one (the "fiction"), and into a history "II", the one that has actually come to pass and is by far different from history I ? Or will she remain stubborn and tell us that we haven't understood what modernity is: the pledge to a perpetual promise?

Whatever kind of response she might give, we likely have perplexed her again. Our "Discourse on Method" (Chapter 3) will disturb our friend. We talk her language, and we talk about her and her views in another language. This language poses, as she cannot help but realize, limits to her discourse and its contents. She sees that we understand her - in that other language. Limitations of all her views, her mentality, her projects emerge. We do not press upon her by explaining the perfect use that our language allows for speaking her language and for defining it. That discursive limits have become apparent, this is the essen-

4 Later in the book we hall quote our friend again. See p. 161. 
tial event. The prevailing modern culture around us is a limited phenomenon. The more we understand modernity, the more we understand this limitation.

\section{The Actuality of Imagination, the Actuality of Things}

Humans know one mode of mental activity by which they can indeed fly away from all impediments towards a world where there are no limits to them at all, nowhere and never. It originates in one of the faculties of their mind: their imagination. This faculty, let us recall, is within the human mind steadily a rival to the faculty of reason. Reason often leads to results of its use that frustrate. Wishes are seen to be beyond fulfillment, practices are discovered not to be desirable, trains of thoughts end up in a deadlock. With imagination, such disappointments and defeats never happen. What you imagine, is present in your mind. Wholly, lastingly, invariably. You are master of the work of your imagination. It is yours, for enjoying it, living with it, beholding in it your genius.

As we shall see in the course of this study, there is in the modern mind a great presence of imagination. We shall hear the people of modernity praise what they imagine, those visions that they fantasize. They take them as proofs of the promises that modernity heralds. Their imagination fills them with enthusiasm. An enthusiasm that we can perfectly understand. A world without limits is imagined.

I am writing this text in my study. It is a rectangular room with four walls, a flat floor and a flat ceiling. There is a door in one wall and in the wall towards the balcony outside there are openings for a large window and a glass door. The room has a three-dimensional shape, with its length, height and width. I could of course imagine a room of another configuration. Perhaps an oval or a circular one? Or a room with a curved ceiling? But I did not build the house of which my study is a part. The house has its structure and most of that structure would have to be altered if I should say: I wish to have a circular instead of a rectangular room for my study. I can freely play with my architectural imaginations, but hardly with the concreteness of architecture and its constraints. I could not use my study if there were no door in one of its walls whereby to enter and leave it.

Architecture - and be it concerned only with the arrangement of rooms in a house - translates images of spatial arrangements and structures (a house, a street, a cluster of buildings) into a spatial actuality of those arrangements and structures. This actuality, however, sharply controls the imagination from which these images originate. If you want to have a room of your own, it has to be an enclosed space. Whatever the structure of it is, this structure has to 
allow for an entrance. But is it just a control? I would need artificial light all the time if my study had no openings. But there are openings through which sunlight can penetrate the room and my eyes can meet the flowers and trees in the garden. Those openings are highly beneficial, they relate me to my existentially true habitat, nature. They contribute thereby to the health of soul and mind. The rules of architecture do not only exert a constraint, they are also wise.

Why? Why, to put the question squarely, is architecture an instance of wisdom? The illustration given by the example of my study may have prepared the response. Architecture, we might observe, keeps humans from letting their imagination run its own course. As builders, architects, city planners, they simply cannot opt out entirely from respecting the primary Gestalt of things. A lot is pre-given here: the fundamental elements of architecture such as circle, square, lines, angles, joints, cavities, measured space, emplacement, dimensions, and proportions. Everyone is free to imagine a house but then it is possible to imagine it only according to the paradigm "house" that is already "there" within the possibilities offered by the fundamental elements of architecture. ${ }^{5}$ The primary Gestalt of things in this world allows humans, invites them indeed, to engage themselves in imaginative creativity. But this creativity precisely is not absolute.

However, the protagonists of modernity apparently think so. Throughout this book we hear the message: Humans are about to make the world and all its parts into what they wish them to be. And this is the evidence that prompts us to evoke and describe the inevitable conflicts that emerge between the assumption of a divine-like status of humankind and the earthly nature of humans, between attempts to let one's demiurgic fantasy play with language and the structures of language pre-existing in the apparatus of the human mind, between the inexhaustible demands of the self-centered Ego and the indispensable concert of views and actions without which no human society could exist. We cannot refrain from pointing out and dealing with the consequences of those conflicts that bear on individuals and societies alike. "Chaos" and "violence" shall be the appropriate descriptive terms to be applied for our analyses.

A reign of human imagination, we shall see, does not liberate, but dehumanizes. Or, to put it positively, human nature rebels against the demands of a reckless imagination. If things are not allowed to be what they are, life, in the end,

5 On the paradigms of architecture cf. further my article "The Cosmology of the Architecture of Cities" in: Diogenes, No. 156, Winter 1991, pp. 1-31 (French version in: Diogène, No. 156, Oct.Dec. 1991, pp. 3-31; Spanish version in: Diógenes (Mexico City), No. 156, Oct.-Dec. 1991, pp. 3-34; Arabic version in: Messbah El Fikr (Cairo), No. 156, May 1994, pp. 1-30); and my book: Die Architektur der Welt. Eine kosmologische Lektüre architektonischer Formen, Munich: Fink, 1997. 
becomes vacuous, dispiriting, infuriating. Outlets are longed for, however excessively. Human nature appears to be resilient. A full experience of modernity, this is the supreme lesson, counters modernity.

\section{The Great Competition}

The people of modernity believe in God. In their own way, though, we have to add at once. They would never speak of the Divine in the way of negative theology, for instance. In their minds, God certainly is not, as negative theology teaches, so utterly removed from human understanding that humans are totally unable to spell out anything about the Divine, and could therefore say only, in speaking about the Divine, what God is not. They often speak of God, the moderns, as will be seen throughout this book. And they do so with much assurance, in displaying in their writings quite precise ideas about the nature and the properties of the "God" who figures there. It is very much their God, it seems.

The predilection of the moderns for their figurations of the Divine may at first astound. At the top of their world, after all, is man (except for some recent feminist provocations, there is but a masculine imagination at play here), unhesitatingly called "King of the Earth (roi de la terre)" by Buffon and Rousseau. ${ }^{6}$ In principle, a God - let's say the God of the Bible - has no place there. The spirit of modernity has taken over and leads man into his own kingdom, the regnum hominis (Francis Bacon's term), ${ }^{7}$ where he will obey but himself.

Why, then, appears "God" so often in the writings of our protagonists? They compete. This is the answer. They wish to have a measure against which they can score the excellence of their thoughts and the supreme status of their knowledge. They need a figuration of Divinity in order to prove that no one, even "God", owns a position with regard to the world other than the one they themselves hold. Under the laws of nature, they claim, "God" and humans are equals. "God", Montesquieu observed, "cannot change the essence of things". 8 The people of modernity are by no means disinclined to discuss things divine, or, in their words, religious matters. Concerning the Great Competition that they conduct, they certainly are not unmusical.

6 See Chapter 6, note 31.

7 See the section The "Kingdom of Man" at the beginning of Chapter 6 .

8 See Chapter 4, note 65. 


\section{Modernity unto Cosmology}

The moderns pluck, in fact, a number of strings of the common cultural sensitivity. All of the actuality of their civilizational project resonates with the cosmos of things from which they desired to take leave. In describing this actuality we continually experience a dichotomy between civilizational desire and civilizational truth: against the attempts of humans to conquer it, nature rebels; a capricious play with language for the purpose of amusement only, has, in order to impress, to be formed into a carefully constructed tale; a silence fills the world that is defined exclusively by geometry and mathematics, and the search of humans for meaning does not cease; the supremacy of the individual is always and everywhere checked, if the existence of a society is the goal.

We speak in this book very often of the "cosmos". Our inquiry into modernity is leading us to do so, from chapter to chapter. The more we comprehend modernity, the more we realize that it pioneers the formulation of a cosmology. Athena's counterpoise, perhaps?

Baierbrunn (County of Munich)

April $20^{\text {th }}, 2020$ 
